\title{
Tingkah laku agresif rusa Timor (Cervus timorensis) jantan di penangkaran pada fase diurnal dan nokturnal
}

\author{
Sally Saurma Silalahi *, Daud Samsudewa, Enny Tantini Setiatin, Yon Soepri Ondho \\ Fakultas Peternakan dan Pertanian, Universitas Diponegoro, Semarang, 50275 \\ *Correspondence: silalahisally@gmail.com
}

Received: June 29th 2020; Accepted: December 23 ${ }^{\text {th }}, 2020$; Published online: March 22 ${ }^{\text {th }}, 2021$

Abstrak

Tujuan: Penelitian ini bertujuan untuk mengetahui perbandingan tampilan tingkah laku agresif rusa Timor jantan dalam mempertahankan betina dan teritori di penangkaran, antara waktu siang hari (diurnal) dan malam hari (nokturnal) dilihat dari durasi, frekuensi, sekuen serta interval tingkah laku.

Metode: Penelitian observasional menggunakan metode pengamatan focal animal sampling, dengan mengamati langsung tingkah laku agresif dari 4 ekor rusa Timor jantan yang sehat, memiliki ranggah keras, dipelihara di lokasi dengan manajemen dan kondisi yang sama. Durasi pengamatan yang dilakukan yaitu 24 jam dan dilakukan selama 7 hari. Parameter yang diamati meliputi durasi, frekuensi, sekuen serta interval dari tingkah laku agresif rusa Timor jantan. Analisis data yang digunakan adalah uji statistik non parametrik Wilcoxon Signed Rank Test (Uji Peringkat Bertanda Wilcoxon).

Hasil: Hasil penelitian menunjukan bahwa terdapat perbedaan nyata pada keempat tingkah laku agresif rusa Timor di waktu diurnal dan nokturnal $(\mathrm{P}<0,20)$ dan pengamatan menampilkan data bahwa durasi dan frekuensi tingkah laku agresif pada rusa Timor antara lain berkubang, berjalan menegakkan kepala, berteriak, menggosokkan ranggah, mengancam, melarikan diri dan memanjat lebih sering dan lebih panjang ditampilkan pada waktu siang hari (diurnal).

Kesimpulan: Perbedaan waktu antara siang hari (diurnal) dan malam hari (nokturnal) menyebabkan durasi dan frekuensi tingkah laku agresif rusa Timor lebih panjang dan lebih sering ditampilkan pada waktu siang hari (diurnal).

Kata Kunci: Agresif; Diurnal; Nokturnal; Rusa Timor; Tingkah Laku

\section{Abstract}

Objective: The aims of this research was known comparison the appearance of aggressive behavior of male Timor deers reared in maintaining females and territories at captivity, between the time of day time (diurnal) and night phase (nocturnal) seen from the duration, frequency, sequence and interval aggresive behavior.

Methods: This observational research used the observation focal animal sampling method, by directly observing the aggressive behavior of 4 male Timor deers in a good condition, have hard antlers and maintained at location with the same management and conditions. The duration of observations was 24 hours and carried out for 7 days. The parameters observed included the 
duration, frequency and interval of aggressive behavior male Timor deers. The data analysis used was the non-parametric statistical test Wilcoxon Signed Rank Test.

Results: The results showed that there were significant differences in the four aggressive behavior of Timor deers at day time and nocturnal phase $(\mathrm{P}<0.20)$ and the observations showed that the duration and frequency of aggressive behavior Timor deers such as wallowing, walking with head up, shouting, rubbing antlers, threatening, running away and climbing more frequently and for longer periods was shown during the day time (diurnal).

Conclusions: Difference time between day time (diurnal) and night phases (nocturnal) causes the duration and frequency aggressive behavior of Timor deers, was longer and more frequent during the day time.

Keywords: Aggressive; Diurnal; Nocturnal; Timor Deer; Behavior

\section{PENDAHULUAN}

Rusa Timor merupakan satwa endemik (asli) dari Indonesia tepatnya berada di hutan Sulawesi [1]. Rusa Timor memiliki potensi yang cukup tinggi sebagai salah satu sumber protein hewani disamping daging sapi dan kambing, namun peningkatan populasi rusa Timor masih sangat rendah. Penurunan populasi rusa Timor selalu terjadi tiap harinya akibat kerusakan habitat dan perburuan liar [2]. Status populasi rusa Timor yang rentan akan kepunahan (vulnerable), menjadi salah satu alasan dari upaya konservasi atau penangkaran rusa Timor yang bertujuan untuk menyelamatkan populasi dari rusa Timor itu sendiri [3].

Keberhasilan penangkaran rusa Timor dapat dilihat dari adanya peningkatan populasi rusa yang dipelihara [4]. Peningkatan populasi rusa Timor dalam penangkaran dapat diketahui dan dibuktikan dengan mengetahui serta memahami perubahan tampilan perilaku agresif rusa Timor jantan pada waktu diurnal dan nokturnal, menurunnya perilaku agresif rusa Timor berdampak pada menurunnya tingkat libido dan dominan hierarki rusa Timor dan mempengaruhi kemampuan rusa Timor dalam memperebutkan betinanya [5].

Perubahan habitat rusa Timor dari alam liar menuju penangkaran di balik pagar, mengakibatkan terjadinya beberapa perubahan, salah satu sifat rusa Timor yang aktif pada malam hari (nokturnal) cenderung menjadi lebih aktif pada siang hari (diurnal) [6]. Berangkat dari permasalahan rendahnya peningkatan populasi rusa Timor pada penangkaran maka perubahan sifat menjadi diurnal dianggap menjadi salah satu penyebab dari rendahnya produktivitas rusa Timor dalam penangkaran dimana peningkatan populasinya hanya berkisar $50 \%$ dari jumlah rusa Timor betina yang dipelihara [7].

Penelitian ini bertujuan untuk mengetahui perbandingan tampilan tingkah laku agresif rusa Timor jantan di penangkaran antara waktu siang hari (diurnal) dan malam hari (nokturnal) dilihat dari durasi, frekuensi, sekuen serta interval tingkah laku. Manfaat dilakukan penelitian ini adalah untuk memberikan informasi kepada penangkar dan calon penangkar mengenai tampilan perilaku agresif dari rusa Timor jantan serta memberi masukan mengenai kondisi penangkaran rusa Timor yang baik untuk menunjang peningkatan populasi.

\section{MATERI DAN METODE}

\section{Materi}

Penelitian dilaksanakan di Penangkaran Rusa Timor atas nama Prof. Dr. Ir. V. Priyo Bintoro, M.Agr. pada lahan Fakultas Peternakan dan Pertanian Universitas Diponegoro yang berlokasi di Jl. Prof. Soedarto, Tembalang, Kecamatan Tembalang, Kota Semarang. Materi yang digunakan dalam penelitian yaitu empat ekor rusa Timor (Cervus timorensis) jantan yang berumur sekitar \pm 4 tahun kondisi sehat, memiliki ranggah keras, dipelihara dalam kandang penangkaran berukuran $\pm 502,5 \mathrm{~m}^{2}$, sistem pemeliharan diumbar namun tetap diberi pakan rutin pada sore hari dan 16 ekor pejantan yang digabungkan dengan 13 betina dewasa serta 2 ekor anak betina. 


\section{Metode}

Metode dalam penelitian ini meliputi tahap penelitian pendahuluan, tahap pengambilan data, dan tahap analisis data. Penelitian pendahuluan dilakukan selama 7 hari sebelum pelaksanaan penelitian sebagai langkah awal sebelum melakukan penelitian. Penelitian pendahuluan meliputi kegiatan pelatihan pengambilan data. Data yang dihasilkan dalam penelitian pendahuluan tidak digunakan untuk analisis. Tahap pengambilan data dilakukan dengan cara pengamatan langsung (observasional) menggunakan metode focal animal sampling. Pengamatan dilakukan dengan mengamati langsung tingkah laku agresif rusa Timor dengan durasi 1.440 menit (24 jam) pada tiap pengambilan data selama 7 hari. Deskripsi mengenai tingkah laku yang diamati selama pengamatan (Tabel 1). Satuan data yang diamati tiap tingkah laku yaitu durasi, frekuensi, interval dan sekuen (Tabel 2).

\section{Analisis Data}

Data yang diperoleh diuji menggunakan statistik non parametrik Wilcoxon Signed Rank Test (Uji Peringkat Bertanda Wilcoxon) untuk mengetahui pengaruh taraf waktu terhadap tingkah laku agresif rusa Timor [8]. Penggunaan materi penelitian sebanyak 4 ekor memenuhi syarat minimum analisis data dengan menggunakan taraf nyata $20 \%$ dan kemudian membandingkannya dengan nilai $\mathrm{T}$ tabel Wilcoxon.

\section{HASIL}

Rekapitulasi perbandingan tingkah laku rusa Timor pada fase diurnal dan nokturnal selama 7 hari pengamatan (Tabel 3). Hasil pengamatan tingkah laku agresif rusa Timor yang dipelihara di penangkaran menampilkan bahwa durasi dan frekuensi tingkah laku agresif lebih sering ditampilkan rusa Timor pada waktu siang hari (diurnal) dengan interval yang lebih panjang pada waktu malam hari namun untuk durasi tingkah laku mendorong serta bertarung lebih panjang dilakukan pada waktu malam hari, hal ini berkaitan dengan tingkah laku rusa Timor jantan yang sering memperebutkan tempat untuk beristirahat.

\section{PEMBAHASAN}

Tingkah laku berkubang rusa Timor jantan pada waktu diurnal dan nokturnal diperoleh hasil berbeda nyata $(\mathrm{P}<0,20)$. Tingkah laku ini lebih sering dilakukan pada waktu diurnal karena pada waktu siang hari banyak digunakan untuk beraktifitas dan waktu malam hari cenderung digunakan

Tabel 1. Ethogram tingkah laku agresif rusa Timor jantan beserta deskripsi

\begin{tabular}{ll}
\hline \multicolumn{1}{c}{ Tingkah Laku } & \multicolumn{1}{c}{ Deskripsi } \\
\hline Berkubang (Wallowing) & Berputar dalam air atau lumpur hingga tubuhnya kotor \\
& kemudian mengguncangkan tubuhnya menunjukkan \\
& kekuasaaan \\
Berjalan menegakkan kepala & Berjalan pelan dengan langkah yang tinggi serta posisi \\
(Walking with Head Up) & kepala yang ditarik menghadap ke atas \\
Berteriak (Shouting) & Berteriak dengan suara yang keras dan nada tinggi \\
Menggosokkan ranggah & Menempatkan kepala pada posisi \pm 45o ke bawah, menuju \\
(Rubbing Anthler) & objek dengan bagian dalam tandung yang menyentuh objek \\
& dan menggosokkannya ke arah atas-bawah \\
Ekspresi mengancam & Posisi siap untuk berkelahi dan kepala menunduk dengan \\
(Expression of Threat) & posisi tanduk yang horizontal \\
Mendorong (Pushing) & Mendorong bagian kepala dari pejantan lain. Ini merupakan \\
& sebuah tanda yang sangat mengancam \\
Bertarung (Actual fighting) & Posisi kepala ke kepala dengan tanduk yang mengunci dan \\
& mencoba melukasi pejantan yang lain \\
Melarikan diri (Fleeing) & Pejantan yang kalah dalam pertarungan akan melarikan diri \\
Memanjat (Climbing) & Memanjat untuk menunjukkan kemenangan \\
\hline
\end{tabular}

Sumber : Samsudewa [20] 
untuk beristirahat. Sofyan dan Setiawan [9] menyatakan bahwa perilaku berkubang pada siang hari dilakukan rusa Timor jantan untuk menstabilkan suhu tubuhnya ketika cuaca cerah dan saat sinar matahari terik. Berkubang merupakan awal tingkah laku agresif rusa Timor jantan seperti persiapan bertarung dengan pejantan lain, Zumrotun et al. [10] berpendapat bahwa perilaku berkubang bertujuan mengotori tubuh dan untuk menarik perhatian dari rusa Timor betina dan merupakan awal tingkah laku agresif rusa Timor jantan.

Tingkah laku menegakkan kepala rusa Timor jantan pada waktu diurnal dan nokturnal menggunakan uji peringkat bertanda Wilcoxon diperoleh hasil berbeda nyata $(\mathrm{P}<0,20)$. Tingkah laku ini adalah tingkah laku lanjutan setelah rusa jantan mengotori tubuhnya. Nuraini et al. [11] berpendapat bahwa setelah mengotori tubuhnya rusa Timor akan mulai berjalan sambil mengangkat sedikit kepalanya dengan tujuan memamerkan bentuk tubuhnya untuk menarik perhatian rusa Timor betina. Berdasarkan analisis rerata frekuensi tingkah laku agresif rusa Timor ini cenderung dilakukan pada siang menuju sore hari yaitu sebesar 1,44 kali, rusa Timor lebih aktif berkelompok pada siang menuju sore hari. Tingkah laku ini juga tingkah laku refleks ketika mendapat ancaman dari lingkungannya. Amiati et al. [12] menyatakan bahwa tingkah laku menegakkan kepala merupakan tingkah laku spontan yang akan diperlihatkan rusa Timor ketika mendapat gangguan baik gangguan dalam perebutan makanan atau gangguan dalam pertarungan memperebutkan wilayah ataupun betina.

Hasil analisis untuk tingkah laku berteriak rusa Timor jantan pada waktu diurnal dan nokturnal diperoleh hasil berbeda nyata $(\mathrm{P}<0,20)$. Bunga et al. $[6]$ berpendapat bahwa tingkah laku berteriak pada rusa

Tabel 2. Parameter pengamatan penelitian beserta deskripsi

\begin{tabular}{ccl}
\hline Pengamatan & Satuan & \multicolumn{1}{c}{ Deskripsi } \\
\hline Durasi & Detik & Rentang waktu atau lamanya tingkah laku agresif \\
Frekuensi & Kali & $\begin{array}{l}\text { Jumlah kejadian tingkah laku agresif } \\
\text { Sekuen }\end{array}$ \\
Interval & Menit & $\begin{array}{l}\text { Jrutan tingkah laku agresif } \\
\text { Jarak munculnya tingkah laku agresif satu dengan tingah laku } \\
\text { agresif lainnya }\end{array}$ \\
\hline
\end{tabular}

Sumber : Bunga et al. [2]

Tabel 3. Rekapitulasi perbandingan tingkah laku rusa Timor pada fase diurnal dan nokturnal selama 7 hari pengamatan

\begin{tabular}{|c|c|c|c|c|c|c|c|}
\hline \multirow{2}{*}{ No. } & \multirow{2}{*}{ Tingkah Laku } & \multicolumn{2}{|c|}{ Durasi } & \multicolumn{2}{|c|}{ Frekuensi } & \multicolumn{2}{|c|}{ Interval } \\
\hline & & Diurnal & Nokturnal & Diurnal & Nokturnal & Diurnal & Nokturnal \\
\hline & & \multicolumn{2}{|c|}{-------(detik)------- } & \multicolumn{2}{|c|}{-------(kali)------- } & \multicolumn{2}{|c|}{-------(menit)------- } \\
\hline 1. & Berkubang & $39,72^{a}$ & $4,11^{\mathrm{b}}$ & $1,55^{a}$ & $0,56^{\mathrm{b}}$ & $30,16^{a}$ & $77,69^{\mathrm{b}}$ \\
\hline 2. & $\begin{array}{l}\text { Berjalan } \\
\text { menegakkan } \\
\text { kepala }\end{array}$ & $6,55^{\mathrm{a}}$ & $2,32^{\mathrm{b}}$ & $1,44^{\mathrm{a}}$ & $0,75^{\mathrm{b}}$ & $69,02^{a}$ & $87,74^{b}$ \\
\hline 3. & Berteriak & $1,15^{\mathrm{a}}$ & $0,01^{\mathrm{b}}$ & $1,69 \mathrm{a}$ & $0,25^{\mathrm{b}}$ & $0,02^{\mathrm{a}}$ & $27,02^{\mathrm{b}}$ \\
\hline 4. & $\begin{array}{l}\text { Menggosokkan } \\
\text { ranggah }\end{array}$ & $75,26^{a}$ & $33,36^{\mathrm{b}}$ & $2,98^{\mathrm{a}}$ & $2,57^{b}$ & $39,7^{a}$ & $48,68 b$ \\
\hline 5. & $\begin{array}{l}\text { Ekspresi } \\
\text { mengancam }\end{array}$ & $6,65^{\mathrm{a}}$ & $5,42^{b}$ & $7,32^{a}$ & $3,38^{\mathrm{b}}$ & $86,96^{a}$ & $106,77 \mathrm{~b}$ \\
\hline 6. & Mendorong & $7,64^{a}$ & $18,41^{\mathrm{b}}$ & $4,29^{a}$ & $2,11^{b}$ & $98,83^{a}$ & $124,41^{\mathrm{b}}$ \\
\hline 7. & Bertarung & $40,61^{a}$ & $76,57^{b}$ & $15,54^{a}$ & $9,08^{\mathrm{b}}$ & $28,31^{a}$ & $55,56^{b}$ \\
\hline 8. & Melarikan diri & $6,30^{a}$ & $1,93^{\mathrm{b}}$ & $2,04^{a}$ & $1,56^{\mathrm{b}}$ & $44,93^{a}$ & $63,67 \mathrm{~b}$ \\
\hline 9. & Memanjat & $3,79 a$ & $0,35^{\mathrm{b}}$ & $0,99 a$ & $0,04^{\mathrm{b}}$ & $0,14^{a}$ & $0,06^{\mathrm{b}}$ \\
\hline
\end{tabular}

Keterangan : Superskrip yang berbeda pada baris dan kolom antar parameter yang sama menunjukkan perbedaan yang nyata $(\mathrm{P}<0,20)$. 
Timor merupakan tingkah laku sosial yang memiliki tujuan untuk menarik perhatian dan memanggil betina yang hendak dikawininya. Tingkah laku berteriak yang diamati merupakan tingkah laku yang diikuti dengan tingkah laku agresif lainnya. Perbedaan nyata terlihat pada frekuensi dan durasi tingkah laku berteriak, tingkah laku ini ditampilkan lebih singkat pada waktu nokturnal, karena aktivitas rusa Timor jantan di dalam penangkaran cenderung lebih banyak dilakukan pada waktu diurnal yaitu 1,69 kali. Hal ini dipengaruhi oleh lokasi perkandangan dekat dengan jalan yang cenderung berisik pada waktu diurnal saat jam kerja dan tenang pada waktu nokturnal. Menurut Nugroho [13] pada habitat aslinya rusa Timor aktif pada waktu nokturnal dimana kegiatan rusa Timor sangat dipengaruhi oleh predator, namun setelah masuk kedalam penangkaran, rusa Timor beradaptasi dengan lingkungannya dan akan lebih aktif pada waktu diurnal menyesuaikan dengan kondisi penangkaran yang cenderung ramai di siang hari.

Tingkah laku menggosok ranggah rusa Timor jantan pada waktu diurnal dan nokturnal menggunakan uji peringkat bertanda Wilcoxon. Hasil pengamatan memperlihatkan bahwa tingkah laku ini cenderung lebih lama dilakukan rusa Timor pada pagi dan menjelang sore hari dengan durasi 75,26 detik, ketika cahaya matahari tidak terlalu menyengat, sehingga rusa Timor akan lebih aktif berpindah untuk menandai daerah kekuasaanya. Nuraini et al. [11] mengatakan bahwa tingkah laku ini bertujuan untuk memberi penandaan pada wilayah teritorinya dan sebagai upaya perlawanan terhadap ancaman maupun gangguan sekitarnya.

Hasil analisis uji peringkat bertanda Wilcoxon terhadap data durasi, frekuensi dan interval untuk tingkah laku mengancam rusa Timor jantan pada waktu diurnal dan nokturnal diperoleh hasil berbeda nyata $(\mathrm{P}<0,20)$. Tingkah laku mengancam adalah tanda awal penyerangan yang akan dilakukan rusa Timor jantan, sebagai respon ketika ada gangguan dari lingkungan kemudian dilanjutkan tingkah laku agresif mendorong. Tingkah laku ini terjadi lebih sering sebanyak
7,32 kali pada waktu diurnal, menurut Kwatrina et al. [14] bahwa pada keadaan siang menuju sore hari rusa Timor cenderung lebih sensitif terhadap perubahan dan gangguan, jika mendapat ancaman rusa Timor jantan dengan spontan akan membalikkan badan dan mengarahkan ranggah menuju pejantan lain yang memberi ancaman.

Hasil analisis data memperoleh hasil berbeda nyata $(\mathrm{P}<0,20)$. Pejantan akan mulai memberi dorongan sebagai awal pertarungan dalam memeperebutkan pakan ataupun betina sebagai bentuk perlawanan untuk mengusir pejantan lain yang memasuki teritorialnya. Pengamatan tingkah laku memperlihatkan bahwa rusa Timor dalam penangkaran lebih aktif di waktu diurnal dimana menampilkan sebanyak 4,29 kali, juga dipengaruhi oleh intensitas cahaya matahari. Hal ini didukung oleh Dewi dan Wulandari [15] bahwa rusa Timor lebih aktif di waktu siang menuju sore hari ketika cahaya matahari yang sudah tidak terlalu menyengat termaksud aktivitas makan dan di antara aktivitas diselingi dengan aktivitas istirahat yang singkat, sehingga pada waktu malam hari digunakan untuk beristirahat penuh.

Hasil analisis uji peringkat bertanda Wilcoxon terhadap data durasi, frekuensi dan interval untuk tingkah laku bertarung rusa Timor jantan pada waktu diurnal dan nokturnal diperoleh hasil berbeda nyata $(\mathrm{P}<0,20)$. Frekuensi tingkah laku bertarung lebih sering ditampilkan pada waktu siang hari sebanyak 15,54 kali. Tingkah laku ini merupakan lanjutan seusai rusa Timor jantan mulai mendorong pejantan lainnya dan perkelahian dilakukan dengan saling menggesekkan ranggah sembari memberi dorongan terhadap pejantan lawan sampai menghasilkan satu pemenang. Aktivitas sosial rusa Timor seperti bertarung cenderung dilakukan pada siang menuju sore hari. Bunga et al. [6] berpendapat tingkah laku bertarung dilakukan lebih singkat pada malam hari dikarenakan aktivitas makan, sosial dan berpindah cenderung lebih banyak dilakukan rusa Timor jantan pada waktu diurnal.

Hasil analisis data durasi, frekuensi dan interval untuk tingkah laku melarikan diri rusa Timor jantan pada waktu diurnal 
dan nokturnal menggunakan uji peringkat bertanda Wilcoxon diperoleh hasil berbeda nyata $(\mathrm{P}<0,20)$. Tingkah laku melarikan diri berhubungan dengan tingkah laku bertarung. Tingkah laku ini dilakukan oleh rusa Timor jantan yang kalah setelah pertarungan. Semakin sering tingkah laku bertarung muncul di waktu diurnal maka akan berbanding lurus dengan tingkah laku melarikan diri. Adiati dan Brahmantiyo [16] berpendapat bahwa tingkah laku melarikan diri dilakukan oleh rusa Timor jantan yang kalah. Rusa Timor yang merasa terancam atau terganggu akan mengalami penegakan bulu di sekujur tubuhnya, diakhiri dengan mengeluarkan suara lengkingan. Menurut Gusmalinda [17] rusa Timor jantan yang kalah akan menundukkan kepala sambil berlari ke arah yang berlawanan dengan pejantan yang menang. Tingkah laku ini cenderung dilakukan pada siang menuju sore hari.

Hasil analisis uji peringkat bertanda Wilcoxon terhadap data durasi, frekuensi dan interval untuk tingkah laku memanjat rusa Timor jantan pada waktu diurnal dan nokturnal diperoleh hasil berbeda nyata $(\mathrm{P}<0,20)$. Tingkah laku ini berkaitan dengan tingkah laku bertarung. Tingkah laku ini dilakukan pejantan yang memenangkan pertarungan kemudian memanjat dataran yang tebih tinggi seperti gundukan tanah. Samsudewa dan Susanti [18] menyatakan bahwa tingkah laku memanjat adalah tingkah laku yang umumnya dilakukan pemenang dari perkelahian sebagai tanda kemenangan dan sebagai tanda kekuasaan setelah berhasil mendapatkan betina yang ingin dikawini.

Perubahan sifat rusa Timor menjadi aktif di siang hari (diurnal) dikarenakan setelah berpindahnya rusa Timor ke dalam penangkaran rusa Timor melakukan adaptasi yang baik terhadap situasi penangkaran yang cenderung ramai dan sibuk baik oleh pengendara maupun pengunjung pada waktu pagi hingga sore hari dan cenderung lebih tenang pada waktu malam hari. Menurut Pratiwi [19] bahwa perilaku rusa Timor akan berpengaruh dengan kondisi lokasi pemeliharaan dimana rusa Timor memiliki respon yang tinggi akan adanya ancaman maupun gangguan dari luar. Tingkah laku istirahat rusa Timor akan ditampilkan ketika rusa Timor merasa nyaman dan aman [20]. Perubahan sifat rusa Timor menjadi aktif di siang hari (diurnal) dikarenakan setelah berpindahnya rusa Timor ke dalam penangkaran rusa Timor melakukan adaptasi yang baik terhadap situasi penangkaran yang cendrung ramai dan sibuk baik oleh pengendara maupun pengunjung pada waktu pagi hingga sore hari dan cenderung lebih tenang pada waktu malam hari.

\section{KESIMPULAN}

Perbedaan waktu antara siang hari (diurnal) dan malam hari (nokturnal) mempengaruhi tampilan tingkah laku agresif rusa Timor. Pengamatan terhadap tampilan tingkah laku agresif rusa Timor yang dipelihara di penangkaran menampilkan hasil bahwa terdapat perbedaan nyata pada bahwa durasi, frekuensi dan interval tingkah laku agresif lebih panjang dan lebih banyak ditampilkan rusa Timor pada waktu siang hari (diurnal).

\section{KONFLIK KEPENTINGAN}

Penulis menyatakan tidak ada konflik kepentingan dengan organisasi keuangan mana pun terkait materi yang dibahas dalam naskah. Penelitian ini didanai oleh Kementerian Riset dan Teknologi namun para penyandang dana tidak memiliki peran dalam desain penelitian, dalam pengumpulan data, tahap analisis data, tabulasi data, penulisan naskah atau dalam pengambilan keputusan dalam menerbitkan hasilnya.

\section{UCAPAN TERIMA KASIH}

Ucapan terima kasih sebesar-besarnya untuk Kementerian Riset dan Teknologi karena telah mendanai penelitian ini melalui program Dana Hibah Penelitian Mahasiswa Universitas Diponegoro Tahun 2019. Kepada Daud Samsudewa, S.Pt., M.Si., Ph.D., Dr. drh. Enny Tantini Setiatin, M.Sc. serta Dr. Ir. Yon Soepri Ondho, M.S. selaku pembimbing yang selalu memberikan arahan, kritikan, masukan serta motivasi sehingga dapat menyelesaikan tulisan ini. Pihak Fakultas Peternakan dan Pertanian Universitas Diponegoro yang telah 
bersedia dijadikan lokasi penelitian dan bersedia digunakan fasilitasnya.

\section{REFERENSI}

1. Puspitasari, A., B. Masy'ud dan T. Sunarminto. 2016. Keterkaitan Persepsi dan Perilaku Pengunjung Terhadap Kesejahteraan Rusa Timor di Taman Satwa Cikembulan Garut. Media Konservasi, 20(1), 1-12.

2. Santosa, Y., R. T. Kwatrina dan A. P. Kartono. 2012. Penentuan sistem penangkaran rusa timor (Rusa timorensis de Blainville 1822) berdasarkan jatah pemanenan dan ukuran populasi awal. Media Konservasi, 17(2). 1-14.

3. Semiadi, G., I. M. J. Adhi and A. Trasodiharto. 2005. Calving pattern on captive sambar deer (Cervus unicolor) in East Kalimantan. Biodiversitas. DOI: 10.13057/biodiv/d060112

4. Bunga, R., M. M. Kawatu, R. S. H. Wungow dan J. J. Rompas. 2018. Aktivitas harian rusa Timor (Cervus timorensis) di Taman Marga Satwa Tandurusa Aertembaga, Bitung-Sulawesi Utara. Zootec Trop, 38(2), 345-356. DOI: 10.35792/zot.38.2.2018.20111

5. Utomo, M. B. dan A. R. Hasan. 2014. Kajian Partisipasi Masyarakat dan Peran Pemerintah dalam Kegiatan Penangkaran dan Konservasi Eksitu Rusa Timor di Provinsi Nusa Tenggara Barat. JPSEK, 11(2),12-19. DOI: 10.20886/jpsek.2014.11.2. 165-173

6. Wirdateti, W., M. Mansur dan A. Kundarmasno. 2005. Behavioural Study of Timor Deer (Cervus timorensis) in PT Kuala Tembaga, Aertembaga Village, BitungNorth Sulawesi. JAP, 7(2); 1-10.

7. Samsudewa, D., S. S. Capitan, C. C. Sevilla, R. S. A. Vega and P. P. Ocampo 2017. Body measurements and testosteron level of male Timor deer (Rusa timorensis) at various hierarchies. J. of Indonesian Tropical Animal Agriculture, 42(4), 227232.

8. Wilcoxon, F., S. K. Katti and R. A. Wilcox. 1970. Critical values and probability levels for the Wilcoxon rank sum test and the Wilcoxon signed rank test. Selected tables in mathematical statistics, 1, 171-259.
9. Sofyan, I. dan A. Setiawan. 2018. Studi Perilaku Harian Rusa Timor (Cervus timorensis) Di Penangkaran Rusa Tahura Wan Abdul Rachman. J-BEKH, 5(1), 67-76.

10. Zumrotun, B. Masyud dan A. M. Thohari. 2006. Peranan sanrego (Lunasia amara Blanco) dalam peningkatan libido seksual rusa Timor (Cervus timorensis de Blainville, 1822) jantan (The Role of Sanrego (Lunasia amara Blanco) to Increasing Libido Sexual of Male Timor Deer (Cerous timorensis de Blainville). Media Konservasi, 11(2).

11. Nuraini, R., D. Samsudewa dan S. Sutiyono. 2018. Pengaruh Jumlah Pejantan Rusa Timor (Rusa timorensis) Perkandang Terhadap Tampilan Tingkah Laku. Dalam Prosiding Seminar Nasional Kebangkitan Peternakan III:" Hilirisasi Teknologi Peternakan pada Era Revolusi Industri 4.0". Semarang. 3 Mei 2018. Hal 17-21.

12. Amiati, D. A., B. Masyud dan R. Garsetiasih. 2016. Pengaruh Pengunjung terhadap Perilaku dan Pola Konsumsi Rusa Timor (Rusa timorensis de Blainville 1822) di Penangkaran Hutan Penelitian Dramaga. Buletin Plasma Nutfah, 21(2), 47-60. DOI: 10.21082/blpn.v21n2.2015.p4760

13. Nugroho, N. P. 2014. Kandungan Biomassa atas Permukaan pada Hutan Rawa Gambut di Kabupaten Rokan Hilir, Provinsi Riau (The Above-Ground Biomass Content in Peat Swamp Forest at Rokan Hilir District, Riau Province). J. Penelitian Hutan dan Konservasi Alam, 11(1), 12-25. DOI: 10.20886/jphka.2014.11. 1.41-51

14. Kwatrina, R. T., M. Takandjandji dan M. Bismark. 2018. Ketersediaan tumbuhan pakan dan daya dukung habitat Rusa timorensis de Blainville, 1822 di kawasan hutan penelitian Dramaga. Buletin Plasma Nutfah. 21(1), 12-30.

15. Dewi, B. S. dan E. Wulandari. 2011. Studi perilaku harian rusa sambar (Cervus unicolor) di Taman Wisata alam Bumi Kedaton. JPS MIPA, 17(2), 75-78.

16. Adiati, U. dan B. Brahmantiyo. 2015. Karakteristik Morfologi Rusa Timor (Rusa timorensis) di Balai Penelitian Ternak Ciawi. Dalam Prosiding Seminar Nasional Teknologi Peternakan dan 
Veteriner, Bogor (Indonesia): Balai Penelitian Veteriner, Dr. Wisri Puastuti: 1013 Desember. Hal. 596-600.

17. Gusmalinda, R., B. S. Dewi dan N. W. Masruri. 2018. Social Behavior of Sambar Deer (Cervus unicolor) and Spotted Deer (Axis axis) in Gunung Madu Plantations Inc. Sanctuary Lampung Tengah. J. Sylva Lestari, 6(1), 74-84.

18. Samsudewa, D. dan S. Susanti. 2006. Studi Tingkah Laku Reproduksi Rusa Timor (Cervus timorensis) sebagai Upaya Penangkaran di Kepulauan Karimun Jawa. Laporan Akhir DIK RUTIN 2006. Hal;1-12.

19. Pratiwi, W. D. 2019. Etnokonservasi Masyarakat Desa Pangandaran Tentang
Pelestarian Rusa Timor (Rusa timorensis) di Taman Wisata Alam/Cagar Alam Pananjung Pangandaran. Fakultas Kehutanan. Universitas Gadjah Mada. Yogyakarta. (Tesis)

20. Nurcahyo, W. 2015. Monitoring of Physiological and Parasites Status of Bawean Deer (Axis Kuhlii) in Its Habitat as a Baseline for Wildlife Conservation Endeavor. JVS, 33(2), 126-133.

21.Samsudewa, D. 2012. Reproductive behavior, hematology profiles, testosterone level and semen quality of male Timor deer. Master of Science in Agricultural Chemistry. University of the Philippines Los Baños. Philippines. (Disertation) 